\title{
Analisis Rekonstruksi Sikap Sosial Siswa Tuna Rungu
}

\author{
I Wayan Widiana ${ }^{1 *}$, I Gede Nurjaya ${ }^{2}$, Gede Wira Bayu ${ }^{3}$, Putu Wiwin Noviana ${ }^{4}$
}

1 Prodi PGSD, Fakultas Ilmu Pendidikan, Universitas Pendidikan Ganesha

2 Prodi Pendidikan Bahasa Indonesia, Fakultas Bahasa dan Seni, Universitas Pendidikan Ganesha

${ }^{3}$ Prodi PGSD, Fakultas Ilmu Pendidikan, Universitas Pendidikan Ganesha

${ }^{4}$ Prodi PGSD, Fakultas Ilmu Pendidikan, Universitas Pendidikan Ganesha

\section{A R T I C LEINFO \\ Article history: \\ Received 18 August 2019 \\ Received in revised form \\ 19 September 2019 \\ Accepted 25 October 2019 \\ Available online 30 \\ November 2019}

Kata Kunci:

sikap sosial, rekonsruksi

tuna rungu.

Keywords:

social attitude, reconstruction,

hearing impaired

\section{A B S T R A K}

Latar belakang yang mendorong penelitian ini adalah (1) sikap sosial yang dimiliki siswa tuna rungu, (2) deskripsi efektivitas rekonstruksi sikap sosial melalui pendekatan sainstifik. Populasi dan sampel dalam penelitian ini adalah seluruh siswa tuna rungu dan seluruh siswa kelas IV SD Negeri 2 Bengkala Kecamatan Kubutambahan Kabupaten Buleleng. Metode yang digunakan adalah pemberian kuesioner dan wawancara guru dengan teknik analisis deskriptif kulitatif dan kuantitatif. Hasil penelitian menunjukkan bahwa (1) deskripsi sikap sosial yang dimiliki siswa kelas IV SD Negeri 2 Bengkala secara umum memiliki rata-rata $(87,21)$ termasuk dalam kategori tinggi. Namun hasil rata-rata indikator pada aspek sikap gotong royong $(7,5)$ termasuk dalam kategori rendah, sikap disiplin $(7,14)$ termasuk dalam kategori rendah, sikap sopan $(7,43)$ termasuk dalam kategori rendah, dan sikap percaya diri $(6,5)$ termasuk pada kategori sangat rendah. (2) deskripsi efektivitas rekonstruksi sikap sosial siswa kelas IV SD melalui pendekatan saintifik hanya diterapkan pada indikator sikap sosial yang berada dibawah kategori tinggi. Hasil secara umum rata-rata $(41,64)$ berada pada kategori sangat tinggi, hasil rata-rata dari setiap indikator yang direkonstruksi yaitu gotong royong $(8,56)$ berada pada kategori tinggi, disiplin (11) berada pada kategori sangat tinggi, sopan $(10,4)$ berada pada kategori sangat tinggi, dan percaya diri $(10,7)$ berada pada kategori sangat tinggi. Demikian deskripsi pendekatan saintifik dalam merekonstruksi sikap sosial dikatakan efektif karena hasil perhitungan rata-rata mengalami kenaikan.

\section{A B S T R A C T}

The background that support this research are (1) the social attitudes of deaf students, (2) a description of the effectiveness of social attitude reconstruction through a scientific approach. The population and sample in this research were all deaf students and all fourth grade students of SD Negeri 2 Bengkala, Kubutambahan District, Buleleng Regency. The method used is the provision of questionnaires and teacher interviews with qualitative and quantitative descriptive analysis techniques. The results showed that (1) the description of social attitudes possessed by fourth grade students of SD Negeri 2 Bengkala in general had an average (87.21) included in the high category. However, the average results of indicators on aspects of mutual cooperation (7.5) are included in the low category, discipline (7.14) is included in the low category, polite attitude (7.43) is included in the low category, and is confident 6,5 ) included in the very low category. (2) description of the effectiveness of the reconstruction of social attitudes of elementary school students in grade IV through a scientific approach only applied to social attitude indicators that are under the high category. The general results (41.64) are in the very high category, the average yield of each reconstructed indicator is mutual cooperation (8.56) in the high category, discipline (11) in the very high category, polite (10.4) in the very high category, and confidence (10.7) is in the very high category. Thus the description of the scientific approach in reconstructing social attitudes is said to be effective because the results of the average calculation increase.

1 Corresponding author.

E-mail addresses: wayan_widiana@yahoo.com (I Wayan Widiana) 


\section{Pendahuluan}

Sikap merupakan sebuah tingkah laku atau perilaku yang ditunjukan seseorang untuk merespon sebuah objek. Berbagai pandangan muncul mengenai esensi sikap. Sikap merupakan sebuah ekspresi dan nilai-nilai atau pandangan hidup yang dimiliki oleh seseorang (Kurniasih, 2014). Cara seseorang memandang suatu permasalahan sangat bergantung pada sikap yang dimiliki, termasuk pula sikap yang dimiliki oleh siswa dalam menyelesaikan permasalahan yang ditemui dalam proses pembelajaran.

Menurut Gerungan, W.A $(2004 ; 161)$ attitude itu dapat diterjemahkan dengan sikap terhadap obyek tertentu, yang merupakan sikap pandangan atau sikap perasaan, tetapi sikap tersebut disertai oleh kecenderungan untuk bertindak sesuai dengan sikap obyek itu. Jadi attitude itu dapat diterjemahkan sebagai sikap dan kesediaan beraksi terhadap suatu hal. Attitude itu senantiasa terarahkan terhadap suatu hal atau suatu obyek. Tidak ada attitude tanpa adanya obyek.

Berdasarkan beberapa pendapat tersebut dapat disimpulkan bahwa sikap adalah keadaan diri dalam manusia yang menggerakkan untuk bertindak atau berbuat dalam kegiatan sosial dengan perasaan tertentu di dalam menanggapi obyek situasi atau kondisi di lingkungan sekitarnya. Selain itu sikap juga memberikan kesiapan untuk merespon yang sifatnya positif atau negatif terhadap obyek atau situasi.

Jika sikap dikaitkan dalam pendidikan, Undang-undang RI. No. 20 Tahun 2003 tentang Sistem Pendidikan Nasional mengamanahkan agar pendidikan tidak hanya memberi kesempatan untuk membentuk insan Indonesia yang cerdas semata, tetapi juga berkepribadian atau berkarakter, sehingga nantinya akan lahir generasi bangsa yang tumbuh dan berkarakter yang terdapat nilai-nilai luhur bangsa dan agama. Pendidikan Nasional juga berfungsi mengembangkan kemapuan, membentuk kemampuan dan membentuk watak seseorang. Kemampuan dan watak seseorang dapat dibentuk pada saat mendapat pendidikan. Pendidikan yang terjadi dilingkungan sekolah sering disebut pendidikan formal, sebab sudah memiliki rancangan pendidikan berupa kurikulum tertulis yang disusun secara sistematis. Untuk jenjang pendidikan sekolah dasar lebih menekankan dalam pembentukan sikap.

Jika sikap dikaitkan dengan pendidikan di sekolah dasar, tujuan pendidikan di sekolah dasar yaitu sebagai proses pengembangan kemampuan yang paling mendasar agar siswa belajar secara aktif karena adanya dorongan dalam diri siswa secara optimal. Perkembangan diri siswa akan lebih optimal jika siswa dapat mengembangkan sikap sosial pada diri mereka.

Sikap sosial mengajarkan siswa bagaimana bersikap dengan lingkungan sekitar yang di dalamnya termasuk guru, teman, orang tua, saudara, dan masyarakat. Sikap sosial membuat siswa terbiasa menumbuhkan sikap jujur, disiplin, tanggung jawab, gotong royong, toleransi, sopan, dan percaya diri. Sikap sosial akan terbentuk dari jenjang pendidikan sekolah dasar.

Selain dari dalam diri siswa sendiri, guru juga memiliki peranan penting dalam membimbing siswa mengenai sikap sosial di sekolah. Guru merupakan profesi multiperan. Bukan hanya menjadi seorang ahli mengajar, manager pembelajaran, peneliti, praktisi, akan tetapi guru juga bertindak sebagai seorang konselor menurut Susetyo (dalam Irine Kurniastuti, 2011). Peran ini sangat nampak terutama bagi seorang guru Sekolah Dasar (SD) yang notabene menjadi pejuang tunggal yang harus memerankan semua peran tersebut. Sebagai seorang konselor, guru bertugas memberikan berbagai layanan bimbingan dan konseling. Guru diharapkan membantu seluruh peserta didik dalam memenuhi kebutuhan-kebutuhan intelektual, emosional, sosial-personal agar dapat mengaktualisasikan tugas-tugas perkembangannya yang meliputi aspek pribadi-sosial, akademik/pendidikan, dan karier sesuai dengan tuntutan lingkungan menurut Barus \& Hastuti (dalam Irine Kurniastuti, 2011).

Pada Kenyataan dilapangan guru dalam pelaksanaan pembelajaran hanya lebih terfokus pada penggunaan model dan bagaimana upaya menciptakan suasana yang efektif, namun kurang menekankan pada dimensi sikap khususnya sikap sosial yang dimiliki siswa serta sikap sosial siswa belum tampak sepenuhnya. Dapat terlihat saat awal siswa tiba di sekolah masih terlihat siswa terlambat hadir ke sekolah, kemudian saat kegiatan proses pembelajaran berlangsung siswa masih terlihat bercanda dengan teman, mengganggu teman, ataupun siswa masih kurang memiliki rasa kebersamaan dalam menyelesaikan tugas yang diberikan guru. Perilaku tersebut tentu menunjukkan sikap sosial siswa pada aspek gotong royong dan disiplin belum sesuai dengan harapan.

Permasalahan tersebut diperkuat dengan hasil observasi awal yang telah dilakukan pada tanggal 7 Januari 2019 bahwa sikap sosial di SD Negeri 2 Bengkala Kecamatan Kubutambahan Kabupaten Buleleng perlu dilakukan rekonstruksi mengenai sikap sosial siswa seperti saat mengikuti proses pembelajaran siswa tuna wiacara lebih pasif karena cendrung diam saat mengikuti pembelajaran. Pada saat jam istirahat siswa tuna wicara cenderung memilih untuk sendiri dari pada berinteraksi dengan temannya. Hal ini juga didasarkan hasil wawancara pada tanggal 8 Januari 2019 terhadap guru di SD Negeri 2 Bengkala menyatakan bahwa sikap sosial yang dimiliki pada masing-masing siswa mengalami penurunan, Guru tidak selalu memantau sikap siswa termasuk sikap sosial siswa. Guru juga mengatakan 
bawah dalam proses pembelajaran dan berinteraksisi, siswa masih mengalami kesulitan karena karakter siswa tuna wicara yang memiliki hambatan berbahasa-bicara, dan kebanyakan guru masih kurang memahami bahasa dari anak tuna wicara yang mengakibatkan kurangnya komunikasi antara guru dengan siswa tuna wicara.

Sikap sosial yang terlihat menyimpang seperti tidak mengerjakan tugas kelompok yang diberikan oleh guru, tidak memperhatikan guru saat proses pembelajaran berlangsung, dan terlambat datang ke sekolah hal tersebut yang menjadikan guru harus memberikan teguran, bimbingan, nasihat, atupun pembinaan terhadap siswa terkait. Walaupun guru telah melakukan beberapa cara untuk mengatasi sikap sosial siswa yang menyimpang, permasalahan mengenai sikap sosial masih saja terjadi dan perlu direkonstruksi. Dengan adanya permasalahan di atas dijadikan tujuan untuk direkonstruksi sikap sosial siswa yang belum terlihat secara maksimal menjadi tampak sepenuhnya bahkan hingga berkembang dengan baik, rekonstruksi dilakukan dengan cara pembiasaan. Pembiasaan yang dimaksudkan yaitu dalam proses pembelajaran harus diterapkan berulang-ulang kalis sikap sosial tersebut agar siswa terbiasa bersikap sosial yang baik dalam proses pembelajaran.

\section{Metode}

Jenis penelitian yang digunakan dalam penelitian ini yaitu penelitian deskriptif. Pada dasarnya, "Penelitian deskriptif dipersiapkan untuk memperoleh informasi mengenai suatu fenomena yang terjadi" Darmadi, (2014:184). Adapun tujuan dari penelitian ini yaitu, "Memberi gambaran secara sistematis faktual, dan akurat mengnai fakta-fakta dan sifat-sifat yang diselidiki" Darmadi (2014:300).

Penelitian ini dilaksanakan di SD Negeri 2 Bengkala Kecamatan Kubutambahan Kabupaten Buleleng Tahun Pelajaran 2018/2019. Penelitian ini dilaksanakan pada rentang waktu semester II (genap) tahun pelajaran 2018/2019 mulai dari bulan april sampai mei. Penelitian ini berakhir sampai awal Bulan Mei dikarenakan telah diperoleh data yang jenuh atau tidak ada data yang dianggap baru kemudian dapat diuji reliabilitas data.

Prosedur kegiatan pada penelitian ini mengikuti tahapan penelitian deskriptif secara umum. Terdapat tiga tahapan penelitian deskriptif secara umum. Tahapan tersebut meliputi tahap persiapan, tahap pelaksanaan di lapangan, dan tahap pasca lapangan. Tahapan persiapan yang dilakukan ada lima tahap, pada tahapan pelaksanaan di lapangan terdapat tiga tahap, dan tahapan pasca lapangan terdapat dua tahapan.

Metode pengumpulan data yang dilakukan pada penelitian ini untuk mengetahui sikap sosial siswa yaitu dengan menggunakan metode kuesioner (angket) sikap sosial siswa yang diisi oleh siswa kelas IV untuk mengetahui data mengenai gambaran sikap sosial yang dilakukan sebelum dan sesudah pembelajaran disekolah berlangsung, serta metode wawancara untuk mengetahui kendala-kendala yang ditemukan dalam merekonstruksi sikap sosial siswa kelas IV. Metode pengumpulan data tersebut dilakukan secara alami tanpa memberikan perlakuan khusus terlebih dahulu.

Instrumen dalam sebuah penelitian merupakan hal yang sangat penting dalam rangka pengumpulang data sebagai kajian dalam penelitian tersebut, suatu instrumen dapat dikatakan layak untuk dipakai dalam suatu penelitian apabila dilakukan pengujian atau dalam hal ini biasa disebut dengan uji validitas instrumen. Uji Validitas Instrumen digunakan untuk mengetahui kelayakan butir-butir dalam suatu daftar pertanyaan dalam mendefinisikan suatu variabel. Daftar pertanyaan ini pada umumnya mendukung suatu kelompok variabel tertentu. Uji Validitas sebaiknya dilakukan pada tiap butir pertanyaan di uji validitaskan. Hasil $r$ hitung kita bandingkan dengan $r$ tabel dimana $d f=n-2$ dengan signifikansi 5\%. Jika $r$ tabel < r hitung maka valid. Validitas dalam penelitian ini ditinjau dari dua segi yaitu validitas isi dan validitas butir. Validitas instrumen dalam penelitian ini adalah sebagai berikut.

Teknik analisis data yang digunakan dalam penelitian ini adalah analisis deskriptif kualitatif dan analisis deskriptif kuantitatif. Pada penelitian ini, metode analisis data deskriptif kuantitatif digunakan untuk menggambarkan bagaimana sikap sosial awal yang dimilki siswa kelas IV sebelum serta sesudah direkonstruksi dan deskriptif kuantitatif digunakan untuk mendeskripsikan bagaimana kendala-kendala dalam merekonstruksi sikap sosial siswa tunawicara pada siswa kelas IV.

\section{Hasil dan Pembahasan}

Deskripsi dan analisis data penelitian ini menggambarkan data yang diperoleh melalui analisis lembar kuesioner sikap sosial yang diisi oleh siswa kela IV di SD Negeri 2 Bengkala yang terdiri dari 14 responden. Hasil perhitungan yang berupa angka selanjutnya di konversi ke dalam kategori sikap sosial sesuai dengan panduan teknis penelitian di sekolah dasar yang menunjukkan siswa berada di kategori sikap sosial sangat tinggi, tinggi, sedang, rendah, dan sangat rendah. Hasil lembar kuesioner sikap sosial 
siswa kelas IV dapat dilihat pada lampiran. Analisis lembar kuesioner sikap sosial dilakukan secara deskriptif bertujuan untuk memaparkan sikap sosial siswa kelas IV di SD Negeri 2 Bengkala Kecamatan Kubutamahan Kabupaten Buleleng.

Deskripsi data dari sikap sosial siswa kelas IV secara keseluruhan di SD Negeri 2 Bengkala Kecamatan Kubutambahan Kabupaten Buleleng baik secara keseluruhan ataupun pada masing-masing aspek sikap sosial yang terdiri dari aspek jujur, disiplin, tanggung jawab, toleransi, gotong royong, sopan, dan percaya diri.

Hasil wawancara digunakan sebagai penunjang data yang diperoleh melalui lembar kuesioner sikap sosial. Data sikap sosial diperoleh melalui instrumen lembar kuesioner dan transkip wawancara yang digunakan dalam penelitian ini. Berikut deskripsi data dari sikap sosial siswa kelas IV di SD Negeri 2 Bengkala Kecamatan Kubutamahan Kabupaten Buleleng pada masing-masing aspek sosial.

Data sikap sosial siswa di SD Negeri 2 Bengkala Kecamatan Kubutamahan Kabupaten Buleleng diperoleh melalui analisis lembar kuesioner yang diisi olh siswa kelas IV yang terdiri dari 14 orang siswa. Data sikap sosial siswa diperoleh dengan menggabungkan aspek sikap sosial pada penelitian ini yang terdiri dari aspek jujur, tanggung jawab, toleransi, gotong royong, disiplin, sopan, dan percaya diri.

Kualitas sikap sosial siswa kelas IV dapat ditentukan dengan cara skor rata-rata dikonversikan ke dalam kriteria rata-rata ideal (Xi) dan standar deviasiideal (SDi). Pedoman konbersi disajikan dalam Tabel 1 .

Tabel 1. Pedoman Konversi Rata-Rata Ideal Dan Standar Deviasi Ideal Skala Lima

\begin{tabular}{cc}
\hline Rentang Skor & Kategori \\
\hline $97,5 \leq X<120$ & Sangat Tinggi \\
$82,5 \leq X<97,5$ & Tinggi \\
$67,5 \leq X<82,5$ & Sedang \\
$52,5 \leq X<67,5$ & Rendah \\
$30 \leq X<52,5$ & Sangat Rendah \\
\hline
\end{tabular}

Berdasarkan hasil konversi, skor rata-rata sikap sosial siswa kelas IV SD Negeri 2 Bengkala Kecamatn Kubutambahan Kabupaten Buleleng dengan $(X)=87,21$. Termasuk kategori tinggi, hasil perhitungan disajikan pada lampiran.Jumlah siswa kelas IV di SD Negeri 2 Bengkala Kecamatan Kubutambahan Kabupaten Buleleng pada masing-masing kategori skor sikap sosial siswa kemudian dianalisis dengan deskriptif persentase. Berikut ini disajikan analisis jumlah siswa dalam bentuk persentase. Data persentase siswa menurut kategori sikap sosial siswa kelas IV di SD Negeri 2 Bengkala Kecamatan Kubutambahan Kabupaten Buleleng dapat dilihat pada tabel 2.

Tabel 2. Distribusi Frekuensi Data Sikap Sosial Siswa

\begin{tabular}{|c|c|c|c|c|c|c|c|}
\hline No & Aspek sikap sosial & Indikator & ST & $\mathbf{T}$ & $\mathbf{S}$ & $\mathbf{R}$ & SR \\
\hline 1 & Jujur & $\begin{array}{l}\text { mengungkapkan perasaan } \\
\text { apa adanya } \\
\text { 2. mengerjkan ulangan } \\
\text { dengan tidak mencontek }\end{array}$ & $35 \%$ & $50 \%$ & $15 \%$ & $0 \%$ & $0 \%$ \\
\hline 2 & Tanggung Jawab & $\begin{array}{l}\text { 1. menerima resiko dari } \\
\text { tindakan yang dilakukan } \\
\text { 2. menepati janji }\end{array}$ & $64 \%$ & $36 \%$ & $0 \%$ & $0 \%$ & $0 \%$ \\
\hline 3 & Toleransi & $\begin{array}{l}\text { 1. mampu bekerja sama } \\
\text { dengan siapapun yang } \\
\text { memiliki keragaman latar } \\
\text { belakang } \\
\text { 2. menerima kesepakatan } \\
\text { meskipun berbeda dengan } \\
\text { pendapat yang dimiliki }\end{array}$ & $43 \%$ & $43 \%$ & $14 \%$ & $0 \%$ & $0 \%$ \\
\hline 4 & Gotong Royong & $\begin{array}{l}\text { menyelesaikan masalah } \\
\text { dengan bekerjasama }\end{array}$ & $14 \%$ & $29 \%$ & $21 \%$ & $19 \%$ & $7 \%$ \\
\hline 5 & Disiplin & $\begin{array}{l}\text { 1. datang tepat waktu } \\
\text { kesekolah }\end{array}$ & $7 \%$ & $22 \%$ & $14 \%$ & $57 \%$ & $0 \%$ \\
\hline 6 & Sopan & 1. mengucapkan terimakasih & $7 \%$ & $14 \%$ & $36 \%$ & $43 \%$ & $0 \%$ \\
\hline
\end{tabular}


setelah menerima bantuan orang lain

$7 \quad$ Percaya Diri

1. $\begin{aligned} & \text { berani berpendapat, } \\ & \text { bertanya, atau } \\ & \text { menjawab pertanyaan }\end{aligned}$

Data hasil kuesioner indikator-indikator sikap sosial siswa kelas IV diperoleh melalui instrumen kuesioner sikap sosial terhadap14 siswa, masing-masing indikator diukur dengan kuesioner yang terdiri dari 30 butir pertanyaan. Namun skor tertinggi yang diperoleh disajikan berdasarkan masing-masing ampek sikap sosial. Hasil kuesioner dicari mean, kemudia kualitas sikap sosial siswa kelas IV pada masing-masing indikator dapat ditentukan dengan cara skor rata-rata dikonversikan ke dalam kriteria rata-rata ideal (Xi) dan standar deviasi ideal (SDi). Pedeoman konversi masing-masing indikator disajikan berdasarkan aspek sikap sosial. Pada aspek sikap jujur, sikap tanggung jawab, dan sikap toleransi dapat dilihat dalam tabel 3, sedangkan aspek sikap gotong rotong, sikap disiplin, sikap sopan, dan sikap percaya diri dapat dilihat pada tabel 4 .

Tabel 3. Pedoman konsersi rata-rata ideal dan standar deviasi ideal skla lima indikator sikap jujur, tanggung jawab, dan toleransi

\begin{tabular}{cl}
\hline Rentang skor & Ketegori \\
\hline $19,5 \leq X<24$ & Sangat tinggi \\
$16,5 \leq X<19,5$ & Tinggi \\
$13,5 \leq X<16,5$ & Sedang \\
$10,5 \leq X<13,5$ & Rendah \\
$6 \leq X<10,5$ & Sangat rendah \\
\hline
\end{tabular}

Tabel 4. Pedoman konversi rata-rata ideal dan standar devisiasi ideal skala lima indikator sikap gotong royong, disiplin, sopan, dan percaya diri

\begin{tabular}{cl}
\hline Rentang skor & Ketegori \\
\hline $9,75 \leq X<12$ & Sangat tinggi \\
$8,25 \leq X<9,75$ & Tinggi \\
$6,75 \leq X<8,25$ & Sedang \\
$5,25 \leq X<6,75$ & Rendah \\
$3 \leq X<5,25$ & Sangat rendah \\
\hline
\end{tabular}

Berikut adalah deskripsi data skor indikator sikap sosial siswa kelas IV di SD Negeri 2 Bengkala, meliputi sikap jujur. Tanggung jawab, toleransi, gotong royong, disiplin, sopan, dan percaya diri.

Hasil analisis lembar kuesioner sikap sosial ampek jujur yang terdiri dari indikator mengungkapkan perasaan apa adanya dan indikator mengerjakan ulangan dengan tidak menyontek didapatkan hasil seperti pada tabel 2 .

Pada tabel 2 diatas, indikator mengungkapkan perasaan apa adanya dan mengerjakan ulangan dengan tidak menyontek siswa yang berada pada kategori sangat tinggi sebesar 35\%, sedangkan untuk siswa yang berada pada kategori tinggi sebesar 50\%, siswa yang berada pada kategori sedang sebesar $15 \%$, lalu siswa yang berada pada kategori rendang sebesar $0 \%$, dan siswa yang berada pada kategori sangat rendah sebesar 0\%. Data tersebu, diketahui rata-rata dari skor sikap sosial aspek jujur siswa kelas IV Di SD Negeri 2 Bengkala yairu $(X)=19$ termasuk kategori tinggi. Hasil perhitungan disajikan pada lampiran.

Penjabaran data sikap sosial aspek jujur dengan indikator mengungkapkan perasaan apa adanya dan mengerjakan ulangan dengan tidak mencontek tersebut diperoleh secara keseluruhan dari siswa kelas IV.

Hasil analisi lembar kuesioner sikap sosial aspek tanggung jawab yang terdiri dari indikator menerima resiko dari tindakan yang dilakukan dan indikator menepati janji didapatkan hasil seperti pada tabel 2. Pada tabel 2 diatas, indikator menerima resiko dari tindakan yang dilakukan dan menepati janji siswa yang berada pada kategori sangat tinggi sebesar 64\%, sedangkan untuk siswa yang berada pada kategori tinggi sebesar 36\%, siswa yang berada pada kategori sedang sebesar $0 \%$, lalu siswa yang berada pada kategori rendah sebesar $0 \%$, dan siswa yang berada pada kategori sangat rendah sebesar $0 \%$. Data 
tersebu, diketahui rata-rata dari skor sikap sosial aspek jujur siswa kelas IV Di SD Negeri 2 Bengkala yairu $(X)=20,17$ termasuk kategori sangat tinggi. Hasil perhitungan disajikan pada lampiran.

Penjabaran data sikap sosial aspek tanggung jawab dengan indikator menerima resiko dari tindakan yang dilakukan dan indikator menepati janji tersebut diperoleh secara keseluruhan dari siswa kelas IV.

Hasil analisi lembar kuesioner sikap sosial aspek toleransi yang terdiri dari indikator mampu bekerja sama dengan siapapun yang memiliki keragaman latar belakang, pandangan, serta keyakinan dan indikator menerima kesepakatan meskipun berbeda dengan pendapat yang dimiliki didapatkan hasil seperti pada tabel 2.

Pada tabel 2 diatas, indikator mampu bekerja sama dengan siapapun yang memiliki keragaman latar belakang dan menerima kesepakatan meskipun berbeda dengan pendapat yang dimiliki, siswa yang berada pada kategori sangat tinggi sebesar 43\%, sedangkan untuk siswa yang berada pada kategori tinggi sebesar $43 \%$, siswa yang berada pada kategori sedang sebesar $14 \%$, lalu siswa yang berada pada kategori rendang sebesar $0 \%$, dan siswa yang berada pada kategori sangat rendah sebesar $0 \%$. Data tersebu, diketahui rata-rata dari skor sikap sosial aspek jujur siswa kelas IV Di SD Negeri 2 Bengkala yairu $(X)=$ 18,93 termasuk kategori tinggi. Hasil perhitungan disajikan pada lampiran.

Penjabaran data sikap sosial aspek toleransi dengan indikator mampu bekerja sama dengan siapapun yang memiliki keragaman latar belakang dan indikator menerima kesepakatan meskipun berbeda dengan pendapat yang dimiliki tersebut diperoleh secara keseluruhan dari siswa kelas IV.

Hasil analisi lembar kuesioner sikap sosial aspek gotong royong yang terdiri dari indikator menyelesaikan masalah dengan bekerja sama didapatkan hasil seperti pada tabel 2 .

Pada tabel 2 diatas, indikator Menyelesikan masalah dengan bekerjasama, siswa yang berada pada kategori sangat tinggi sebesar $14 \%$, sedangkan untuk siswa yang berada pada kategori tinggi sebesar $29 \%$, siswa yang berada pada kategori sedang sebesar $21 \%$, lalu siswa yang berada pada kategori rendang sebesar 19\%, dan siswa yang berada pada kategori sangat rendah sebesar 7\%. Data tersebu, diketahui rata-rata dari skor sikap sosial aspek jujur siswa kelas IV Di SD Negeri 2 Bengkala yairu $(X)=7,5$ termasuk kategori sedang. Hasil perhitungan disajikan pada lampiran. Berdasarkan hasil konvrsi indikator diatas, menunjukan bahwa masih terdapat siswa yang beraa pada kategori sedang, rendah, dan sangat rendah yang begitu banyak sehingga diperlukan rekonstruksi agar kategori siswa bisa berada di kategori tinggi.

Penjabaran data sikap sosial aspek gotong royong dengan indikator menyelesikan masalah dengan bekerjasama tersebut diperoleh secara keseluruhan dari siswa kelas IV.

Hasil analisi lembar kuesioner sikap sosial aspek disiplin yang terdiri dari indikator datang tepat waktu kesekolah didapatkan hasil seperti pada tabel 2.

Pada tabel 2 diatas, indikator datang tepat waktu kesekolah, siswa yang berada pada kategori sangat tinggi sebesar $7 \%$, sedangkan untuk siswa yang berada pada kategori tinggi sebesar $22 \%$, siswa yang berada pada kategori sedang sebesar 14\%, lalu siswa yang berada pada kategori rendang sebesar $57 \%$, dan siswa yang berada pada kategori sangat rendah sebesar $0 \%$. Data tersebut, diketahui rata-rata dari skor sikap sosial aspek jujur siswa kelas IV Di SD Negeri 2 Bengkala yairu $(X)=7,14$ termasuk kategori rendah. Hasil perhitungan disajikan pada lampiran. Berdasarkan hasil konversi indikator diatas, menunjukan bahwa masih terdapat siswa yang berada pada kategori sedang, rendah, dan sangat rendah yang begitu banyak sehingga diperlukan rekonstruksi agar kategori siswa bisa berada di kategori tinggi.

Penjabaran data sikap sosial aspek disiplin dengan indikator datang tepat waktu kesekolah tersebut diperoleh secara keseluruhan dari siswa kelas IV.

Hasil analisi lembar kuesioner sikap sosial aspek sopan yang terdiri dari indikator mengucapkan terimakasih setelah menerima bantuan orang lain didapatkan hasil seperti pada tabel 2 .

Pada tabel 2 diatas, indikator mengucapkan terimakasih setelah menerima bantuan orang lain, siswa yang berada pada kategori sangat tinggi sebesar 7\%, sedangkan untuk siswa yang berada pada kategori tinggi sebesar 14\%, siswa yang berada pada kategori sedang sebesar 36\%, lalu siswa yang berada pada kategori rendang sebesar $43 \%$, dan siswa yang berada pada kategori sangat rendah sebesar $0 \%$. Data tersebut, diketahui rata-rata dari skor sikap sosial aspek sopan siswa kelas IV Di SD Negeri 2 Bengkala yaitu $(X)=7,43$ termasuk kategori rendah. Hasil perhitungan disajikan pada lampiran. Berdasarkan hasil konversi indikator diatas, menunjukan bahwa masih terdapat siswa yang berada pada kategori sedang, rendah, dan sangat rendah yang begitu banyak sehingga diperlukan rekonstruksi agar kategori siswa bisa berada di kategori tinggi.

Penjabaran data sikap sosial aspek sopan dengan indikator mengucapkan terimakasih setelah menerima bantuan orang lain tersebut diperoleh secara keseluruhan dari siswa kelas IV.

Hasil analisi lembar kuesioner sikap sosial aspek percaya diri yang terdiri dari indikator berani berpendapat, bertanya, atau menjawab pertanyaan didapatkan hasil seperti pada tabel 2 .

Pada tabel 2 diatas, indikator berani berpendapat, bertanya, atau menjawab pertanyaan, siswa yang berada pada kategori sangat tinggi sebesar 7\%, sedangkan untuk siswa yang berada pada kategori tinggi 
sebesar 21\%, siswa yang berada pada kategori sedang sebesar 29\%, lalu siswa yang berada pada kategori rendang sebesar 14\%, dan siswa yang berada pada kategori sangat rendah sebesar 29\%. Data tersebut, diketahui rata-rata dari skor sikap sosial aspek spercaya diri siswa kelas IV Di SD Negeri 2 Bengkala yairu $(X)=6,5$ termasuk kategori Sangat rendah. Hasil perhitungan disajikan pada lampira. Berdasarkan hasil konversi indikator diatas, menunjukan bahwa masih terdapat siswa yang berada pada kategori sedang, rendah, dan sangat rendah yang begitu banyak sehingga diperlukan rekonstruksi agar kategori siswa bisa berada di kategori tinggi.

Penjabaran data sikap sosial aspek percaya diri dengan indikator mengucapkan terimakasih setelah menerima bantuan orang lain tersebut diperoleh secara keseluruhan dari siswa kelas IV.

Setelah dilakukan analisis mengenai sikap sosial siswa kelas IV SD Negeri 2 Bengkala, diperoleh hasil siswa kelas IV memiliki rata-rata skor indikator sikap gotong royong, disiplin, sopan, dan sikap percaya diri masing-masing berada pada klasifikasi kategori sedang. Oleh karena itu dilakukan rekonstruksisikap sosial siswa kelas IV. Rekonstruksi dilakukan dengan memberikan pelajaran pada siswa kelas IV menggunakan pendekatan saintifik pada mata pelajaran IPA kelas IV standar kompetensi 10. Dalam proses pembelajaran setelah diberikan pembelajaran, kembali diberikan kuesioner sikap sosial siswa. Data skor rekonstruksi sikap sosial dperoleh dengan penggabungan skor indikator-indikator. Berikut ini adalah dskripsi data hasil penelitian rekonstruksi sikap sosial siswa kelas IV.

Data hasil kuesioner rekonstruksi sikap sosial siswa kelas IV di SDNegeri 2 Bengkal yang diperoleh melalui instrumen lembar kuesioner sikap sosial tehadap 14 siswa, masing-masing indikator diukur dengan 12 pernyataan. Skor maksimal 48, skor minimal 12. Dikatahui mean dari skor sikap sosial siswa kelas IV, yaitu mean $(\mathrm{M})=41,64$.

Kualitas siakp sosial siswa kelas IV dapat ditemukan dengan cara skor rata-rata dikonversikan ke dalam rata-rata ideal (Xi) dan standar devisiasi ideal (SDi). Pedoman disajikan dalam Tabel 5.

Tabel 5. Pedoman Konversi Rata-rata Ideal dan Standar Devisiasi Ideal Skala Lima

\begin{tabular}{cl}
\hline Rentang Skor & Kategori \\
\hline $39 \leq X<48$ & Sangat Tinggi \\
$33 \leq X<39$ & Tinggi \\
$27 \leq X<33$ & Sedang \\
$21 \leq X<27$ & Rendah \\
$12 \leq X<21$ & Sangat Rendah \\
\hline
\end{tabular}

Berdasarkan hasil konversi, skor rata-rata rekonstruksi sikap sosial siswa kelas IV dengan $\mathrm{M}=$ 41,64 termasuk kategori sangat tinggi. Jumlah siswa kelas IV pada masing-masing kategori skor sikap sosial siswa kemudian dianalisis dengan deskriptif persentase. Berikut ini disajikan hasil analisis jumlah siswa dalam bentuk persentase. Data persentase siswa menurut kategori sikap sosial siswa kelas IV dapat dilihat pada tabel 6.

Tabel 6. Distribusi frekuesnsi persentase efektivitas rekonstruksi siswa kelas IV menurut kategori sikap sosial

\begin{tabular}{llll}
\hline No & Ketegori & Frekuesnsi Siswa & Persentase \\
\hline 1 & Sangat Tinggi (ST) & 12 & $86 \%$ \\
2 & Tinggi (T) & 2 & $14 \%$ \\
3 & Sedang (S) & 0 & $0 \%$ \\
4 & Rendah (R) & 0 & $0 \%$ \\
5 & Sangat Rendah (SR) & 0 & $0 \%$ \\
Jumlah Siswa & 14 & $100 \%$ \\
\hline
\end{tabular}

Berdasarkan Tabel 6 terlihat bahwa rekonstruksi sikap sosial siswa sebesar 86\% berada pada kategori sangat tinggi, sebesar $14 \%$ berada pada kategori tinggi, dan sebesar $0 \%$ berada pada kategori sedang. Dan tidak terdapat siswa yang berada pada kategori sangat rendah. Dengan X= 41,64 termasuk dalam kategori dangat tinggi. Hasil tersebut menunjukkan bahwa rekonstruksi sikap sosial siswa klas IV sebagian besar berada pada kategori sangat tinggi dan sebagian kecil berada pada kategori sedang.

Berikut adalah deskripsi data skor setiap indikator sikap sosial siswa kelas IV setelah direkonstruksi, meliputi sikap gotong royong, sikap disiplin, sikap sopan, dan sikap percaya diri. 
Data hasil kuesioner indikator-indikator efektivitas rekonstruksi sikap sosial siswa kelas IV diperoleh melalui instrumen lembar kuesioner terhadap 14 siswa, masing-masing indikator diukur dengan 3 pernyataan. Skor maksimal yang diperoleh adalah 12 dan skor minimal adalah 3. Hasil kuesioner dicari mean, kemudian kualitas sikap sosial siswa kelas IV masing-masing indikator dapat ditentukan dengan cara skor rata-rata dikoversikan ke dalam kriteria rata-rata ideal (Xi) dan standar devisiasi ideal (SDi). Pedoman konversi disajikan dalam tabel 4.14

Data hasil kuesioner rekonstruksi indikator sikap gotong royong terdiri dari 3 butir pernyataan. Skor maksimal yang diperoleh adalah 12 dan skor minimal adalah 3. Diketahui mean dari skor rekonstruksi sikap gotong royong siswa kelas $\mathrm{IV}$, yaitu $(\mathrm{X})=8,56$.

Berdasarkan hasil konversi indikator, skor rata-rata rekonstruksi sikap gotong royong siswa kelas IV dengan $\mathrm{X}=8,56$.

Data hasil kuesioner rekonstruksi indikator sikap disiplin terdiri dari 3 butir pernyataan. Skor maksimal yang diperoleh adalah 12 dan skor minimal adalah 3. Diketahui mean dari skor rekonstruksi sikap disiplin siswa kelas IV, yaitu $(X)=11$.

Berdasarkan hasil konversi indikator, skor rata-rata rekonstruksi sikap disiplin siswa kelas IV dengan $\mathrm{X}=11$.

Data hasil kuesioner rekonstruksi indikator sikap sopan terdiri dari 3 butir pernyataan. Skor maksimal yang diperoleh adalah 12 dan skor minimal adalah 3. Diketahui mean dari skor rekonstruksi sikap sopan siswa kelas IV, yaitu $(X)=10,4$. Berdasarkan hasil konversi indikator, skor rata-rata rekonstruksi sikap sopan siswa kelas IV dengan $\mathrm{X}=10,4$.

Data hasil kuesioner rekonstruksi indikator sikap percaya diri terdiri dari 3 butir pernyataan. Skor maksimal yang diperoleh adalah 12 dan skor minimal adalah 3. Diketahui mean dari skor rekonstruksi sikap gotong royong sisw kelas IV, yaitu $(X)=10,07$. Berdasarkan hasil konversi indikator, skor rata-rata rekonstruksi sikap percaya diri siswa kelas IV dengan $\mathrm{X}=10,7$.

Deskripsi dan anlisis data penelitian ini menggambarkan data yang diperoleh melalui wawancara dengan guru wali kelas IV. Analisis hasil wawancara kendala yang dihadapi dalam mengajarkan sikap sosial oleh guru dilakukan secara deskriptif dengan mereduksi hasil wawancara yang tidak diperlukan dan menggunakan hasil wawancara yang berkaitan dengan kendala yang dihadapi dalam mengajarkan sikap sosial. Hasil wawancara dideskripsikan berdasarkan pemberian kode guru. Pemberian kode guru disajikan pada lampiran. Berikut deskripsi data dari kendala yang dihadapi dalam mengajarkan sikap sosial siswa kelas IV.

Temuan data kendala mengajarkan sikap sosial oleh guru diperoleh pada 25 april 2019. Wawancara terhadap guru diruang guru. Berdasarkan wawancara dengan guru diperoleh informasi bahwa kendala yang dihadapi dalam mengajarkan sikap sosial pada aktivitas pembelajaran yang biasa dirancang dan dilaksanakan di kelas oleh guru yaitu pembelajaran berkelompok, yaitu saat belajar tidak semua siswa bekerja dengan baik dan terkadang siswa hanya bercanda dibandingkan dengan mengerjakan tugas. Adapun cara yang digunakan oleh guru untuk mengatasi siswa yang tidak ikut bekerja sama dalam kelompok dan hanya banyak bercanda yaitu dengan melakukan pengawasan ekstra pada saat proses pembelajaran agar aktivitas siswa yang tidak sesuai saat proses pembelajaran bisa diperkecil.

\section{Simpulan dan Saran}

Hasil Simpulan yang didapat berdasarkan penelitian yang telah dilakukan adalah sebagai berikut : Deskripsi dimensi sikap sosial secara umum yang dimiliki siswa kelas IV SD Negeri 2 Bengkala sebelum direkonstruksi dengan rata-rata skor 87,21 berada pada kategori tinggi (skor maksimal 120), rata-rata per indikator yaitu sikap jujur dengan rat-rata 19 berada pada kategori tinggi ( skor maksimal 24), sikap tanggung jawab dengan rata-rata 20,71 berada pada kategori sangat tinggi ( skor maksimal 24), sikap toleransi dengan rata-rata 18,39 berada pada kategori tinggi ( skor maksimal 24), sikap gotong royong dengan rata-rata 7,5 berada apada kategori sedang ( skor maksimal 12), sikap disiplin dengan rata-rata 7 , 14 berada pada kategori sedang ( skor maksimal 12), sikap sopan dengan rata-rata 7,43 berada pada kategori sedang ( skor maksimal 12), sikap percaya diri dengan rata-rata 6,5 berada pada kategori sedang ( skor maksimal 12).

Efektivitas rekonstruksi sikap sosial secara umum siswa kelas IV dengan rata-rata skor 41,64 yang berada pada kategori sangat tinggi (skor maksimal 48), rata-rata per indikator yang direkonstruksi yaitu sikap gotong royong dengan raa-rata 8,56 berada pada kategori tinggi (skor maksimal 12), sikap disiplin dengan rata-rata 11 berada pada kategori sangat tinggi (skor maksimal 12), sikap sopan dengan rata-rata 10,4 berada pada kategori sangat tinggi (skor maksimal 12), dan sikap percaya diri dengan rata-rata 10,07 berada pada kategori sangat tinggi (skor maksimal 12). 
Kendala yang dihadapi guru dalam mengajarkan sikap sosial pada siswa kelas IV yaitu siswa lebih banyak bercanda dibandingkan mengerjakan tugas, siswa menggangu teman saat proses pembelajaran, siswa terkadang malas menjawab pertanyaan guru, masih terdapat siswa terlambat masuk kelas, waktu untuk melakukan penilaian yang minim, dan lingkungan sekitar siswa sangat berperan dalam melakukan rekonstruksi kepada siswa.

Solusi yang dilakukan dalam mengajarkan sikap sosial kepada siswa kelas IV yaitu dengan pembelajaran secara berkelompok, siswa melakukan pertukaran informasi dengan teman sebaya, siswa membawa buku saku sebagai penghubung guru dengan orang tua siswa, dan melakukan pengamatan langsung kepada siswa.

Saran yang dapat disampaikan berdasarkan penelitian yang telah dilakukan adalah sekolah dapat melakukan pembinaan, bimbingan pada siswa yang mengalami permasalahan pada aspek sikap sosial tertentu yang dialami siswa dengan bekerja sama dengan guru, kepala sekolah, dan orang tua siswa siswa untuk bersama-sama bembina siswa yang mengalami permasalahan sikap sosial. Hal ini dikarenakan sikap sosial siswa tidak hanya terbentuk dilingkungan sekolah saja, tetapi juga lingkungan keluarga dan masyarakat.

\section{Daftar Rujukan}

Adnyana, Nyoman Agus Tri, dkk. 2016. Analisis Rekonstruksi Sikap Sosial Siswa Kelas IV Dan V Sd Gugus Xiii Kecamatan Buleleng. Jurusan PGSD FIP. Jurusan PGSD Vol: 4 No: 1 Tahun: 2016. Singaraja: Undiksha.

Agung, A. A. Gede. 2005.Metode Penelitian Pendidikan. Singaraja: IKIP.

Agung, A. A. Gede. 2012. Buku Ajar Metodologi Penelitian Pendidikan. Singaraja: Undiksha Pers.

Ahmadi, Abu. 2007. Psikologi Sosial. Jakarta: Rineka Cipta.

Alwi, hasan. 2007. Kamus Besar Bahasa Indonesia Edisi Keempat. Jakarta: PT. Balai Pustaka

Candiasa, I. M. 2011. Pengujian Instrumen Penelitian Disertai Aplikasi ITEMAN dan BIGSTEPS. Singaraja: Unit Penerbit Universitas Pendidikan Ganesha.

Daryanto. 2014. Pendekatan Pembelajaran Saintifik Kurikulum 2013. Jakarta: Gava Media.

Gusviani, Evi. 2016. Analisis Kemunculan Sikap Spiritual Dan Sikap Sosial Dalam Kegiatan Pembelajaran Ipa Kelas Iv Sd Yang Menggunakan Ktsp Dan Kurikulum 2013. Jurnal Pendidikan Dasar p-ISSN 2085-1243 Vol. 8. No.1 Januari 2016. Universitas Pendidikan Indonesia.

Gustini. 2010. Pengaruh Model Pembelajaran Konsiderasi Terhadap Sikap Siswa Pada Pola Hidup Bersih dan Sehat.Tersedia pada http:// http://repository.uinjkt.ac.id/dspace/bitstream/123456789/1260/1/98906-GUSTINI-FITK.pdf di akses pada 15 Februari 2019.

Jahja, Yudrik. 2011. Psikologi Perkembangan. Cetakan ke-1. Jakarta: Kencana Pranada Group.

Kosasih, E. 2014. Strategi Belajar dan Pembelajaran Implementasi Kurikulum 2013. Bandung: Yrama Widya.

Koyan, I Wayan. 2012. Statistik Pendidikan Teknik Analisis data Kuantitatif. Undiksha: Singaraja.

Kunandar. 2013. Penilaian Autentik Berdasarkan Kurikulum 2013. Jakarta: PT Raja Grafindo Persada.

Kurniasih, Imasdan Berlin Sani. 2014. Implementasi Kurikulum 2013. Cetakan ke-1. Surabaya: Kata Pena.

Muhibin, Syah. 2005. Psikologi Belajar. Cetakan ke-4. Jakarta: PT Raja Grafindo Persada.

Pemerintahan Republik Indonesia. 2003. Undang-Undang Republik Indonesia Nomer 20 Tahun 2003 Tentang Sistem Pendidikan Nasional. Jakarta. 
Pratiwi, Jamilah Candra. 2015. Sekolah Inklusi Untuk Anak Berkebutuhan Khusus: Tanggapan Terhadap Tantangan Kedepannya. Surakarta, 21 November 2015 ISBN: 978-979-3456-52-2. Tersedia pada http://SKRIPSI/172228-ID-sekolah-inklusi-untuk-anak-berkebutuhan.pdf diakses pada 15 Januari 2019.

Rahim, Abdul. 2016. Pendidikan Inklusif Sebagai Strategi Dalam Mewujudkan Pendidikan Untuk Semua. Trihayu: Jurnal Pendidikan Ke-SD-an, Vol. 3, Nomor 1, September 2016. Tersedia pada http://SKRIPSI/259113-pendidikan-inklusif-sebagai-strategi-dal-869d07aa.pdf diakses pada 15 Januari 2019.

Sugiyono. 2014. Metodologi Penelitian Pendidikan Pendekatan Kuantitaf dan Kualitatif. Bandung: Alfa Beta.

Suwandi, Sarwiji. 2008. Semantik Pengantar Kajian Makna. Yogyakarta: Media Perkas

Walgoto, Bimo. 2003. Psikologi Sosial Suatu Pengantar. Yogyakarta: Andi Offs.

Yuliana, $\quad$ Rissa. $2016 . \quad$ Pola $\quad$ Kuesioner. Tersedia http://guidancecounsellingbivoketang.blogspot.com/2012/01/macam-macamangket.html diakses pada 15 Januari 2019. 